\title{
GENETIC VARIABILITY AND POPULATION STRUCTURE OF GROUPER (Epinephelus suillus) FROM MAKASSAR STRAIT AND BONE BAY, SOUTH SULAWESI, INDONESIA.
}

\author{
Andi Parenrengi*) and Andi Tenriulo*)
}

\begin{abstract}
Random Amplified Polymorphic DNA (RAPD) was employed to determine the genetic variability and population structure of grouper (Epinephelus suillus) from Makassar Strait and Bone Bay, South Sulawesi, Indonesia. Genomic DNA was isolated from preserved muscle tissue using Phenol-Chloroform technique. Among 24-screened arbitrary primers, ten primers (OPA-02, OPA-06, OPA-08, OPA-10, OPA-15, OPA-16, OPA17, OPA-18, OPA-19 and CA-05) were selected to generate RAPD fingerprinting of grouper populations. The ten primers generated a total of 212 fragments (loci) and 120 polymorphic fragments in their size ranging from 250 to $2,500 \mathrm{bp}$. The high polymorphism (60\%) was obtained from Makassar population followed by Bone (59\%) and Pare-Pare populations (50\%). Similarity index of individuals was $0.86 \pm 0.07$ for Pare-Pare, $0.80 \pm 0.11$ for Makassar and $0.82 \pm 0.07$ for Bone population. Fifteen fragments from ten primes were identified as species-specific markers of E. suillus. The UPGMA cluster analysis showed that the dendrogram seemed to be clustered according to their geographical location, where Pare-Pare population was genetically closer to Makassar population $(D=0.20)$ than to Bone population $(D=0.24)$.
\end{abstract}

\section{KEYWORDS: genetic variability, population structure, RAPD finger printing, grouper}

\section{INTRODUCTION}

Groupers (Epinephelus spp.) are popular and highly valued marine food fish in the markets of Southeast Asian countries. Epinephelus suillus is one of the most important commercial marine fishes in Indonesia. Because of its economic importance, genetic variability and population structure of this species need to be investigated in order to design and to implement adequate management and breeding program. Identification and characterization of population unit of grouper are imperative for fisheries management because efficient resource utilization can greatly be achieved by managing on the population level. Genetic variability is an important feature of population both for short-term fitness of individuals and long-term survival of population by allowing adaptation to occur in a changing environmental condition. Genetic variation is also important in farmed population which allows selective breeding and preventing loss of fitness due to inbreeding depression. The most popular and cost-effective method in detection of genetic variation is isozyme electrophoresis. Despite its several positive attributes, isozyme has some limitations such as highly biased genomic sampling (only genes encoding soluble enzyme are surveyed) as well as small number of loci available for study (Fritsch \& Rieseberg, 1996).

Currently, DNA fingerprinting technique is extremely efficient for detection of molecular genetic markers that may be utilized in assessment of genetic variation in fish, differentiation of stocks or populations and fisheries management. The recent development in the

\footnotetext{
* Research Institute for Coastal Aquaculture, Maros, South Sulawesi - Indonesia
} 
detection of genetic polymorphisms is random amplified polymorphic DNA (RAPD). This technique, which is based on the polymerase chain reaction (PCR), amplifies random genomic segments with a single oligonucleotide primer of arbitrary sequence (William et al., 1990). In contrast to isozymes, RAPD provides a more arbitrary sample of the genome and generates essentially unlimited numbers of loci for use in genetic analysis (Fritsch \& Rieseberg, 1996). The major advantages of the RAPD analysis approach are that (1) prior DNA sequence information is not required, (2) laboratory manipulations are simple to perform, (3) large number of samples can be processed quickly, and (4) no radioactive reagent is utilized (Yu \& Pauls, 1994).

The aim of the study was to determine genetic variability and population structure of grouper (E. suillus) populations from South Sulawesi. The data obtained can be used as a useful guidance in breeding programs and genetic improvement strategies of grouper.

\section{MATERIALS AND METHODS}

\section{Collection of Sample}

The grouper (E. suillus) samples were collected from Makassar Strait (Pare-Pare and Makassar) and Bone Bay (Bone) in South Sulawesi, Indonesia (Figure 1). The locations, sample sizes, ranges of body weight and total length are listed in Table 1. Approximately 50 $\mathrm{mg}$ of fresh muscle tissues from each individual were preserved in TNES-Urea buffer (Asahida et al., 1996). The preserved samples were transported at ambient temperature from the field and kept at room temperature in the laboratory prior to DNA extraction.

\section{DNA Extraction}

A Phenol-Chloroform technique was employed to isolate genomic DNA from the preserved muscle tissues. Five hundred microlitres of lysis buffer $(0.5 \mathrm{M} \mathrm{NaCl}, 0.001 \mathrm{M}$ EDTA, $1 \%$ $(\mathrm{w} / \mathrm{v})$ SDS, $0.8 \%(\mathrm{v} / \mathrm{v})$ Triton $\mathrm{X}-100$, and $0.1 \mathrm{M}$ Tris- $\mathrm{HCl}$; at $\mathrm{pH}$ 9.0) were added to the sample

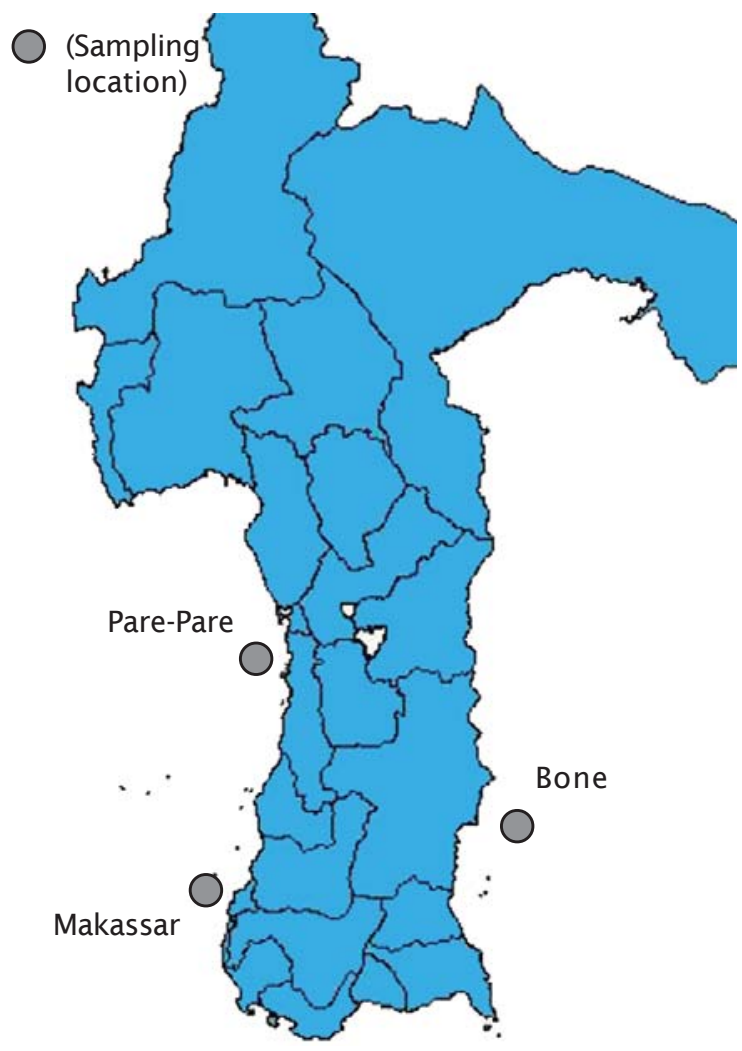

Figure 1. Sampling locations of grouper, Epinephelus suillus 
Table 1. Sampling sites, sample sizes, body weights (BW) and total lengths (TL) of E. suillus samples

\begin{tabular}{lccc}
\hline Location & $\begin{array}{c}\text { Sample size } \\
\text { (ind.) }\end{array}$ & $\begin{array}{c}\text { Range of BW } \\
(\mathbf{g})\end{array}$ & $\begin{array}{c}\text { Range of TL } \\
\text { (cm) }\end{array}$ \\
\hline Pare-Pare & 14 & $47-294$ & $15.0-24.5$ \\
Makassar & 16 & $107-324$ & $18.7-32.5$ \\
Bone & 16 & $45-140$ & $16.9-22.8$ \\
\hline
\end{tabular}

in a $1.5 \mathrm{~mL}$ microcentrifuge tube and followed by adding $40 \mathrm{~mL}$ of $10 \%(\mathrm{w} / \mathrm{v}) \mathrm{SDS}$ and $40 \mathrm{~mL}$ of proteinase $\mathrm{K}(20 \mathrm{mg} / \mathrm{mL}$ solution). The samples were incubated at $55^{\circ} \mathrm{C}$ for 1-3 hours (until completely lysed). The samples were treated with $25 \mathrm{~mL}$ of RNAase $(20 \mathrm{mg} / \mathrm{mL}$ solution) and kept at room temperature for 15-30 minutes. The sample was then treated with 500-600 mL of phenol:chloroform:isoamyl alcohol (25:24:1) and gently vortexed to homogenize it. The samples were again left at room temperature for 10 minutes before centrifuged at 13,000 rpm for 4 minutes. The upper aqueous layer was moved to a new $1.5 \mathrm{~mL}$ microcentrifuge tube. The step of adding phenol:chloroform: isoamyl alcohol (25:24:1) was repeated twice. Sample was treated with one volume of chloroform:isoamyl alcohol (24:1) and centrifuged at 13,000 rpm for 2 minutes. Two volumes of ice-cold absolute ethanol were mixed to the upper aqueous layer by rapid inversion of the tubes several times. Precipitated DNA was collected at the bottom of the tubes in form of a white pellet after centrifuged at 6,000 $\mathrm{rpm}$ for 30 minutes. The pellet was washed with $1 \mathrm{~mL}$ of $70 \%$ ethanol and then spun at 6,000 rpm for 15 minutes. The DNA was left to dry at room temperature and then resuspended with TE buffer (10 mM Tris and $1 \mathrm{mM}$ EDTA, pH 8.0). The genomic DNA was electrophoresed at a $0.8 \%(\mathrm{w} / \mathrm{v})$ horizontal agarose gel at 55 volts for 1-2 hours in $1 \times$ TBE buffer $(0.9 \mathrm{M}$ Tris, $1.1 \mathrm{M}$ Boric acid and 25 mM EDTA at pH 8.3 for $10 \mathrm{X}$ ) and the staining was done in $0.5 \mu \mathrm{g} / \mathrm{mL}$ of ethidium bromide for 20-30 minutes. The purity of genomic DNA obtained was quantitatively estimated from the ratio between the reading of absorbency at $260 \mathrm{~nm}$ and $280 \mathrm{~nm}\left(\mathrm{OD}_{260} /\right.$ $\mathrm{OD}_{280}$ ) and also qualitatively observed through the appearance of a single band on the gel.

\section{Primer Screening}

A total of 24 primers commercially available from Operon Technology Kit A and Gibco-BRL were screened for a randomly single individual sample. Among them, ten primers: OPA-02, OPA06, OPA-08, OPA-10, OPA-15, OPA-16, OPA-17, OPA-1 8, OPA-1 9 and CA-05 (Table 2), based on the clarity and sharpness band formed on the gel, were selected to be used for further analysis.

\section{DNA Amplification}

Amplification reactions were performed in $25 \mathrm{~mL}$ volumes. Each reaction mixture contained 1X PCR buffer; $3.5 \mathrm{mM}$ of $\mathrm{MgCl}_{2} ; 0.4 \mathrm{mM}$ of dNTPs mix (Biotools); $0.4 \mathrm{mM}$ of primer; 2.0 units of taq DNA polymerase (Biotools); and 50 ng of genomic DNA. The genomic DNA was amplified using a GeneAmp PCR system 2400 (Perkin Elmer) which were programmed at 45 cycles for 30 seconds of denaturation at $94^{\circ} \mathrm{C}$, 30 seconds of annealing temperature at $36^{\circ} \mathrm{C}$, one minute of primers extension at $72^{\circ} \mathrm{C}$, and a final extension of two minutes at $72^{\circ} \mathrm{C}$. The negative control, PCR amplification without genomic DNA, was done for every master mix PCR to ensure the contamination of PCR reactions. No amplification product in negative control indicated that the PCR products were not contaminated. A mixture of $10 \mathrm{ml} \mathrm{PCR} \mathrm{product} \mathrm{and}$ $2.5 \mathrm{ml}$ loading dye was run on a $2.0 \%$ agarose gel electrophoresis at 55 volts in 1XTBE for 23 hours and then stained with $0.5 \mathrm{mg} / \mathrm{mL}$ of ethidium bromide for 20-30 minutes. The gel was documented with Image Master VDS (Pharmacia-Technology).

\section{Data Analysis}

The molecular weight of fragments was estimated based on the standard of DNA banding pattern from GeneRuler DNA ladder marker (Fermetas). The fragments were valued as polymorphic when they were absent in some samples (but changes in banding intensity were not valued as polymorphic). Different banding pattern generated by each primer was considered as a different genotype. The presence of fragment was scored as 1 while ab- 
Table 2. Primer code, sequence, nucleotide length and GC content used in Random Amplified Polymorphic DNA analysis

\begin{tabular}{cclcc}
\hline No $^{1}$ & Primer & \multicolumn{1}{c}{ Sequence 5' to $\mathbf{3}^{\mathbf{3}}$} & $\begin{array}{c}\text { Nucleotide } \\
\text { lengt h }\end{array}$ & $\begin{array}{c}\text { GC Cont ent } \\
\text { (\%) }\end{array}$ \\
\hline 1 & OPA-02 & TGCCGACCTC & $10-\mathrm{mer}$ & 70 \\
2 & OPA-06 & GGTCCCTGAC & $10-\mathrm{mer}$ & 70 \\
3 & OPA-08 & GTGACGTAGG & $10-\mathrm{mer}$ & 60 \\
4 & OPA-10 & GTGATCGCAG & $10-\mathrm{mer}$ & 60 \\
5 & OPA-15 & TTCCGAACCC & $10-\mathrm{mer}$ & 60 \\
6 & OPA-16 & AGCCAGCGAA & $10-\mathrm{mer}$ & 60 \\
7 & OPA-17 & GACCGCTTGT & $10-\mathrm{mer}$ & 60 \\
8 & OPA-18 & AGGTGACCGT & $10-\mathrm{mer}$ & 60 \\
9 & OPA-19 & CAAACGTCGG & $10-\mathrm{mer}$ & 60 \\
& & TTCCCACGGATCATGATCAATCAA & & \\
10 & CA-05 & & 24-mer & 41 \\
\hline
\end{tabular}

$1 \quad 1-9=$ Primers from Operon Technologies Inc., $10=$ Commercially synthesized primers from Gibco-BRL

3 Abbreviations: $\mathrm{A}=$ Adenine, $\mathrm{C}=$ Cytosine, $\mathrm{C}=$ Guanine, $\mathrm{T}=$ Thymine

sence was scored as 0 at a particular position or migrated distance on the gel. Data analysis was performed using the program RAPDistance Package Software Version 1.04 (Amstrong et al., 1994) and Numerical Taxonomy and Multivariate Analysis System (NTSYS) Version 1.80 (Rohlf, 1994). The genetic similarity index was calculated across all possible pairwise comparisons of individuals using the formula developed by Nei \& Li (1979). The dendrogram was constructed using Unweighted Pair-Group Method of Aritmethic (UPGMA) employing Sequential, Agglomerative, Hierarchical and Nested Clustering (SAHN) from NTSYS-pc program (Rohlf, 1994).

\section{RESULTS AND DISCUSSION}

\section{DNA Extraction}

The genomic DNA was successfully extracted from preserved muscle tissue by the Phenol-Chloroform technique. A clear single band formed on a $0.8 \%$ agarose gel indicated the high purity of genomic DNA obtained. It is suggested to use the genomic DNA ranging from 1.8-2.0 for PCR requirement (Linacero et al., 1998). However, in this study, genomic DNA in slight lower or more than the range was not found to strongly influence banding patterns. Apun et al. (2000) also reported that the DNA purity (ratio $\mathrm{OD}_{260}: \mathrm{OD}_{280}$ ) ranging from 1.531.96 was sufficiently pure for PCR reaction.
Since the genomic DNA obtained was not degraded and no smearing band was detected on the gel, the DNA amplification of genome was suspected to produce a good RAPD banding pattern.

\section{RAPD Profile}

Different primers generated different RAPD profiles from DNA amplification. The total number of fragments, polymorphic fragments and number of genotypes generated from ten primers were 5-9, 2-6 and 3-7, respectively; and their sizes were ranging from 250 to $2,500 \mathrm{bp}$ (Table 3). The RAPD banding patterns of grouper (E. suillus) generated by primer OPA-02, OPA10, OPA- 17 and OPA-19 are shown in Figure 2.

Variation in the fragment numbers and size ranges generated by different primers within various populations suggest that the difference RAPD profile is due to the difference in the fragment profile. The genotype profile showing the fragment marker comparison between each individual from the same species as a common genotype was chosen as the reference genotype for the analysis of population structure. Some authors reported the number of fragments from different fish species employing the RAPD technique. Six to seventeen fragments were observed in tilapia, Oreochromis spp. (Bardakci \& Skibinski, 1994); one to six fragments in orange roughy, Haplostenthus atlanticus (Smith et al., 1997); 
Table 3. Total number of fragments, polymorphic fragments, and proportion of polymorphism, number of genotypes and size ranges of fragment of $E$. suillus

\begin{tabular}{|c|c|c|c|c|c|c|}
\hline Population & Primer & $\begin{array}{c}\text { Total } \\
\text { number of } \\
\text { fragment }\end{array}$ & $\begin{array}{l}\text { Number of } \\
\text { polymorphic } \\
\text { fragment }\end{array}$ & $\begin{array}{c}\text { Proportion of } \\
\text { polymorphism } \\
\text { (\%) }\end{array}$ & $\begin{array}{c}\text { Number } \\
\text { of } \\
\text { genotype }\end{array}$ & $\begin{array}{c}\text { Size range } \\
\text { of } \\
\text { fragment } \\
\text { (bp) }\end{array}$ \\
\hline \multirow[t]{10}{*}{ Pare-pare } & OPA-02 & 6 & 3 & 50 & 3 & $550-1700$ \\
\hline & OPA-06 & 5 & 2 & 40 & 3 & $250-1500$ \\
\hline & OPA-08 & 6 & 3 & 50 & 5 & $250-800$ \\
\hline & OPA-10 & 7 & 2 & 28.6 & 4 & $300-1300$ \\
\hline & OPA-15 & 6 & 3 & 50 & 3 & $300-1100$ \\
\hline & OPA-16 & 6 & 4 & 66.7 & 5 & $300-800$ \\
\hline & OPA-17 & 8 & 4 & 50 & 5 & 400-1700 \\
\hline & OPA-1 8 & 8 & 3 & 37.5 & 3 & $400-1200$ \\
\hline & OPA-19 & 8 & 6 & 75 & 5 & $320-1700$ \\
\hline & CA-05 & 6 & 3 & 50 & 4 & $300-1200$ \\
\hline \multirow[t]{10}{*}{ Makassar } & OPA-02 & 7 & 3 & 42.9 & 3 & $550-1700$ \\
\hline & OPA-06 & 5 & 3 & 60 & 4 & $250-1500$ \\
\hline & OPA-08 & 9 & 6 & 66.7 & 5 & $300-1200$ \\
\hline & OPA-10 & 8 & 5 & 62.5 & 4 & $400-1500$ \\
\hline & OPA-15 & 8 & 6 & 75 & 5 & $350-1500$ \\
\hline & OPA-16 & 8 & 5 & 66.7 & 5 & $300-1500$ \\
\hline & OPA-17 & 7 & 5 & 71.4 & 3 & $400-1700$ \\
\hline & OPA-1 8 & 8 & 3 & 37.5 & 3 & $300-1200$ \\
\hline & OPA-19 & 8 & 5 & 62.5 & 3 & $320-1700$ \\
\hline & CA-05 & 7 & 4 & 57.1 & 3 & $300-1500$ \\
\hline \multirow[t]{10}{*}{ Bone } & OPA-02 & 7 & 4 & 57.1 & 3 & $550-1700$ \\
\hline & OPA-06 & 6 & 3 & 50 & 3 & $250-2500$ \\
\hline & OPA-08 & 9 & 5 & 55.6 & 6 & $300-1400$ \\
\hline & OPA-10 & 7 & 5 & 71.4 & 7 & $300-1300$ \\
\hline & OPA-15 & 7 & 4 & 57.1 & 3 & $350-1200$ \\
\hline & OPA-16 & 5 & 3 & 60 & 4 & $350-1500$ \\
\hline & OPA-17 & 7 & 5 & 71.4 & 6 & $400-1700$ \\
\hline & OPA-1 8 & 8 & 4 & 50 & 4 & $300-1200$ \\
\hline & OPA-19 & 7 & 4 & 57.1 & 4 & $450-1700$ \\
\hline & CA-05 & 8 & 5 & 62.5 & 3 & $300-1500$ \\
\hline
\end{tabular}

five to eight fragments in Salmo spp. (Elo et al. 1997); five to 16 fragments in striped bass, Morone saxatilis (Bielawski \& Pumo, 1997); and one to 10 fragments in channel catfish, Ictalurus spp. (Liu et al., 1999). Different fragment sizes generated by RAPD technique were also revealed from different species. For instance, the fragment size of 300-2,500bp was detected in Anguilla spp. (Takagi \& Taniguchi, 1995); 600-2,800bp in orange roughy, $H$. atlanticus (Smith et al., 1997); 220-1,270bp in Salmo spp. (Elo et al., 1997); 160-350bp in striped bass, M.saxatilis (Bielawski \& Pumo, 1997); and 200-1,500bp in channel catfish, Ictalurus spp. (Liu et al., 1999).

Bowditch et al. (1993) noted that polymorphism determines the relationship of the group or the taxa; parentage analysis for domestic and wild animal species; identification of in- 


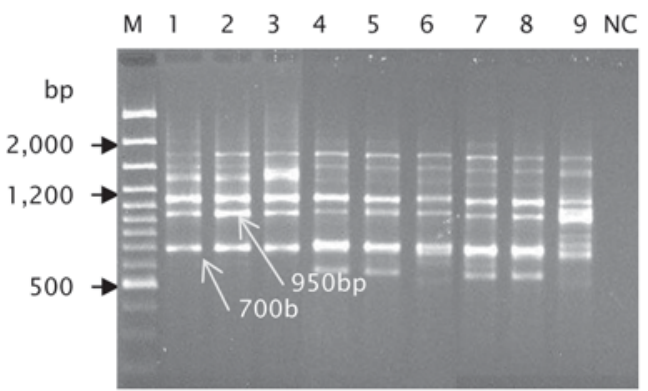

(A)

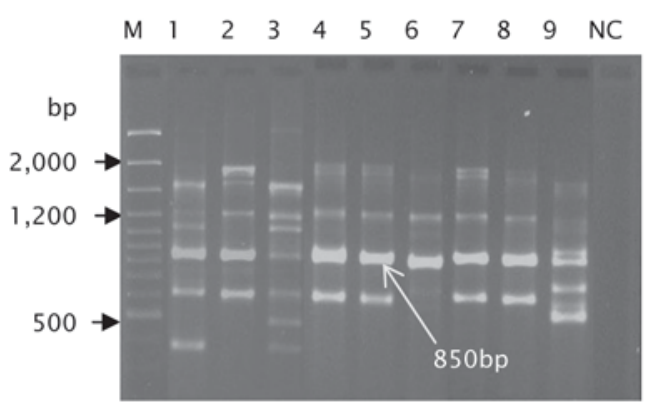

(C)

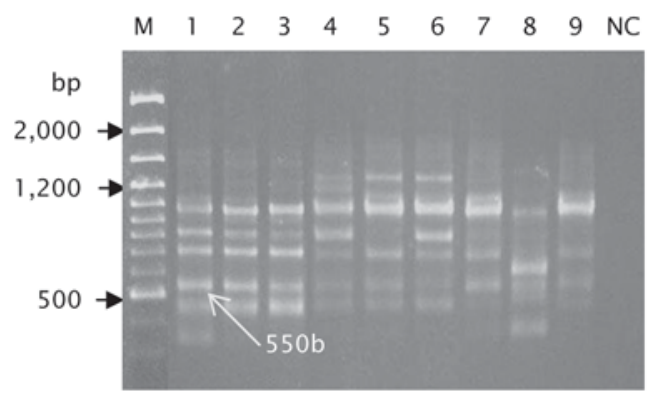

(B)

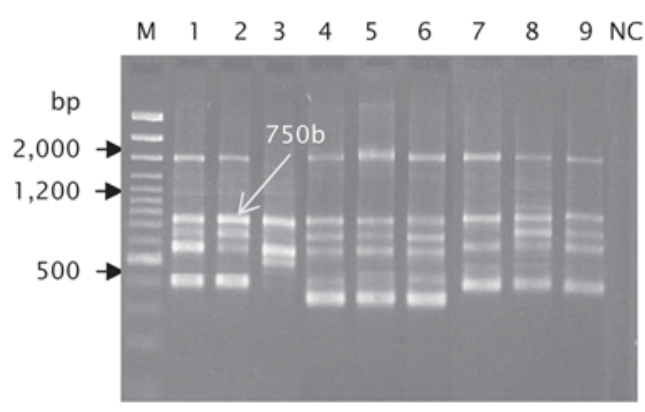

(D)

Figure 2. DNA fingerprinting of E. suillus from different populations generated by primer OPA-02 (A); OPA-10 (B); OPA-1 7 (C) and OPA-19 (D). GeneRuler 100 bp DNA ladder plus (lane M), representative samples of population from Pare-Pare (lanes 1-3), Makassar (lanes 4-6), Bone (lanes 7-9) and negative control (NC). The arrows indicate the speciesspecific-marker of $E$. suillus

dividuals for captive breeding program especially for endangered species; comparison of the wild and the cultivated species; and estimation of the inbreeding or outbreeding level in populations. The high polymorphism (60\%) was obtained from Makassar population followed by Bone (59\%) and Pare-Pare population (50\%)(Table 4). A high polymorphic fragment of all populations indicates a low level of inbreeding among individuals of each population. It is also supported with the fact that the grouper samples were collected from the wild population. High polymorphism detected with RAPD markers is probably due to the preferential amplification of the non-coding repetitive regions of the genome. Since primer is random in nature, coding and non-coding regions may be targeted for PCR amplification.

A level of diversity ranging from $33.33 \%$ $50.00 \%$ was also reported in the population of Pampean freshwater shrimp, Macrobranchium borellii with RAPD marker (D'Amato and Corach, 1996). Garcia \& Benzie (1995) showed a high polymorphism of shrimp (39-77\%) using both RAPD and allozyme markers. The RAPD analysis has also shown the high polymorphisms (85.5\%-98.5\%) among individuals of sea cucumber within the same locality (Norazila, 2000). Similar findings were also detected in the tilapia, O. niloticus population in Lake Albert and Lake Edward (Mwanja et al., 1996) and in striped bass, $M$. saxatilis from five populations (Bielawski \& Pumo, 1997).

\section{Similarity Index}

The similarity index of population $E$. suillus was $0.86 \pm 0.07$ for Pare-Pare, $0.80 \pm 0.11$ for Makassar and $0.82 \pm 0.07$ for Bone. The high similarity index obtained in this study indicates the low degree of variability. Makassar population showed the highest variability while the Pare-Pare population had the lowest variability among individuals within the population. The high similarity indices of intra-populations suggested the genetically closely related individuals in each population. This also indi- 
Table 4. Summary of genetic variability of grouper (E. suillus) from different locations revealed by RAPD analysis

\begin{tabular}{lccc}
\hline & \multicolumn{3}{c}{ Populations } \\
\cline { 2 - 4 } & Pare-Pare & Makassar & Bone \\
\hline Total number of primer & 10 & 10 & 10 \\
Total number of fragment & 66 & 75 & 71 \\
Number of fragment & $6.6 \pm .1 .07$ & $7.5 \pm 1.08$ & $7.1 \pm 1.10$ \\
Number of polymorphic fragment & $3.3 \pm 1.15$ & $4.5 \pm 1.17$ & $4.2 \pm 1.78$ \\
Polymorphism (\%) & 50 & 60 & 59 \\
Number of genotype & $4.0 \pm 0.9$ & $3.8 \pm 0.9$ & $4.3 \pm 1.4$ \\
Size range of fragments (bp) & $250-1700$ & $300-1700$ & $250-2500$ \\
\hline
\end{tabular}

cated that fish samples were collected from the relatively small geographic area for each population. The greatest amount of variation within individuals in Makassar population was also confirmed by the high polymorphism level among individuals (60\%). Similar results on RAPD analysis were reported on the Malaysian river catfish, M. numerus. The intra-population similarity index of $M$. numerus ranged from 0.51 to 0.90 (Kim, 1998; Lim, 1998). Their study revealed unusual genotypes (5.04\%-8.55\%) which decreased the value of the similarity index. This also affected to the difference in the genetic distance in each population. The similarity index among individuals at different populations of striped bass, $M$. saxatilis ranged from 0.92 to 0.96 (Bielawski \& Pumo, 1997). The mean similarity index of the common silver-biddy, Gerres oyena was $0.558 \pm 0.060$ within the Miyazaki population and $0.634 \pm 0.86$ within the Okinawa population (Miyanohara et al., 1999).

\section{Genetic Distance}

The genetic distance obtained varied from 0.20 to 0.24 in pairwise comparison between E. suillus populations. The dendrogram showed that the Pare-Pare population was found to be genetically closer to Makassar population
( $D=0.20)$ than to Bone population ( $D=0.24)$ (Table 5 and Figure 3). The results indicated that geographical distance influences the genetic distance of the grouper population. The important factors affecting gene differentiation among populations are the isolation and the fish genetic drift (gene migration). The genetic drift is the random intergenerational change in gene frequency due to its finite population size (Jorde, 1995). Ferguson et al. (1995) also noted that small isolated populations, genetic variability could be substantially reduced through genetic drift resulting in the loss of alleles and decline in heterozygosity. It is commonly agreed that since the sampling sites of both populations are from neighboring sites located on the Makassar Strait, South Sulawesi waters, Indonesia. Therefore, they might have originated from the same ancestral population and a close genetic relationship is expected. This also suggests that there is frequent migration or gene flow between these populations. The gene flow reduces the genetic distance among populations; when two populations manifest the same genetic distance, they are expected to communicate from one to another via gene flow (Jorde, 1995). The value of genetic distance of $E$. suillus populations re-

Table 5. Genetic distance of RAPD marker in three populations of grouper (E. suillus)

\begin{tabular}{lccc}
\hline & Pare-Pare & Makassar & Bone \\
\hline Pare-Pare & 0.00 & & \\
Makassar & 0.20 & 0.00 & \\
Bone & 0.24 & 0.23 & 0.00 \\
\hline
\end{tabular}



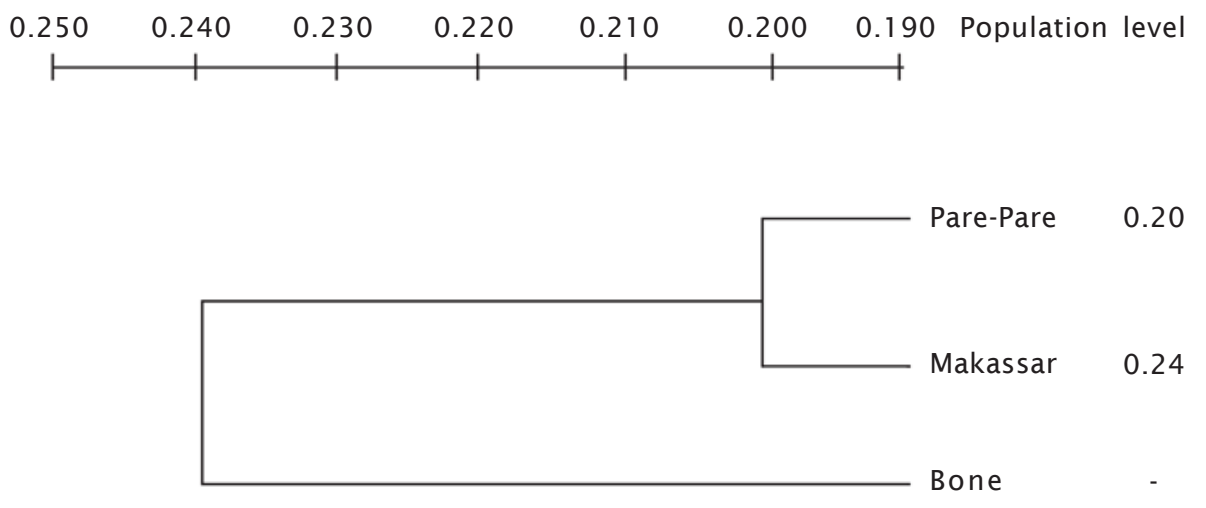

Figure 3. UPGMA cluster analysis based on the genetic distance generated from Nei and Li's indices at different E. suillus populations

vealed by RAPD analysis is substantially wide in the genetic constitution compared to the tilapia (0.04-0.034) (Bardakci \& Skibinski, 1994) and hilsa sad populations (0.08-0.16) (Dahle et al., 1997).

The relatively high genetic distance between Pare-Pare and Bone populations is reflected by the low-shared genetic drift for both populations. The other possible reason could be that the physical separation of the coastal water between the west and east of South Sulawesi continent serves as the geographical barrier and thus restricts the distribution of this species. The dendrogram of catfish, M. numerus revealed by RAPD and AFLP analysis also showed that the Serawak population was genetically different from the other populations studied in Peninsular Malaysia (Kim, 1998); while the population between Kedah and Trengganu showed a higher genetic distance compared to the other studied populations (Lim, 1998). Menezes \& Parulekar (1998) pointed out that the potential genetic differentiation between populations of a species depends upon a number of variables, such as migration rate, the number of individuals within a population and natural selection at different loci.

The effect of the physical barrier on the sciaenid species populations, Nibea mitsukurii was reported by Menezes \& Parulekar (1998). A barrier preventing the gene flow between Tosa Bay and Atsumi Bay caused a spatial genetic discontinuity of this species between these two locations. Geographical isolation was also observed in the brown trout and salmonid species (Ferguson et al., 1995). Hence, the migration as well as the geographic isolation play an important role in causing the current genetic relationships of the populations.

A number of studies have been conducted to determine the influence of geographical distribution and gene flow in populations. The genetic distance of the Japanese sciaenids (Pennahia argentata) sampled from six locations varied between 0.0006-0.0018 (Menezes $\&$ Parulekar, 1998). The low genetic distance in $P$. argentata suggests the occurrence of frequent gene migration flows between populations. This particular species recognizes its habitat and spawning ground in offshore waters than the other species apart from having a wide geographical distribution. In the Atlantic eel (Anguilla rastrata), which has a single spawning ground, there were significant genetic differences between adults and juveniles, and among localities along the east coast of the United States (Smith, 1994). Jorde (1995) illustrated the effect of the migration to the genetic variation of the North American eel and humpback whales. The eels migrated to the Sargasso Sea to reproduce as one massive population and consequently, the individuals inhibiting different streams showed no geographic differentiation. In contrast, the humpback whales inhibiting the same streams but did not leave their home streams to spawn, showed substantial genetic differentiation. It can be concluded that the eels show a very high rate of gene flow while the humpbacks have a low rate of gene flow among sub-populations.

Genetic distance between populations of E. suillus in this study shows its dependence 
with the geographical location. This result suggests that the geographical location of these populations is in agreement with their position in the phylogenic tree. On the other hand, Bielawski \& Pumo (1997) reported that there was no association between genetic distance of populations and geographic distances. They found that the genetic distance of five populations of striped bass exhibited inconsistency to the geographical patterns.

The breeding program can be formulated to increase genetic variation in $E$. suillus from different populations. Based on its high polymorphism and genetic variability, E. suillus from Makassar could potentially be used for manipulation breeding purpose with other populations. As such, this is expected to increase the genetic variation of the grouper species from this breeding purpose. Koh et al. (1999) noted that the reproductive breeding program could be formulated to increase genetic variation within broodstock with high similarity coefficient value by outcrossing with other breeders. This is useful for the breeding program of endangered species. However, it is important to know the degree of genetic relationship of individuals so that deleterious effects from inbreeding can be minimized (Groombridge, 1992). Tam (2000) proposed the formulation of angelfish (Pteropyllum scalare) breeding program based on the similarity coefficient in RAPD analysis. The result of his study suggested that the black, silver and koi varieties could be hybridized to increase their genetic divergence and to avoid inbreeding effects. Koh et al. (1999) reported that the inbreeding among the variety of wild and cultivated Discus species, Symphysodon spp. must be carefully monitored on the basis of their classification and genetic patterns.

\section{Diagnostic Marker}

A diagnostic RAPD marker was observed by the presence of species-specific fragment in all individuals of $E$. suillus from different populations. Based on the RAPD banding pattern from three populations (Figure 2), the fragments of $700 \mathrm{bp}$ and $950 \mathrm{bp}$ from OPA-02; $900 \mathrm{bp}$ from OPA-06; 400bp from OPA-08; 550bp from OPA$10 ; 350 \mathrm{bp}$ from OPA-15; 650bp and 700bp from OPA-16; 850bp from OPA-1 7; 1,200bp, 950bp, $650 \mathrm{bp}$ and $550 \mathrm{bp}$ from OPA-18; $750 \mathrm{bp}$ from OPA-19; and 650bp from CA-05 were observed as species-specific markers of $E$. suillus. The establishment of the species-specific marker on genetic population study of E. suillus is useful for RAPD fingerprinting of this species. Similar finding was reported by Bardakci \& Skibinski (1994). They found that all tested primers (13 RAPD primers) generated the species-specific marker of tilapia. Hadrys et al. (1992) noted that RAPD fingerprinting of genera, species and individuals specific marker is a potential use of polymorphic and non-polymorphic RAPD fragments as diagnostic markers.

The other diagnostic marker of this study is the presence or absence of fragment for all individuals in certain populations. For instance, the fragment $1,100 \mathrm{bp}$ (generated by OPA-15) and 1,550bp (generated by OPA-17) were observed in Pare-Pare population but they were absent in Makassar and Bone populations. These phenomena show the indication of genetic marker in differentiating population. Similar findings on population genetic marker have been reported from the tilapia, tiger barb and sea cucumber. Proportion of tilapia (Oreochromis esculentus) diagnostic bands that appeared in particular population was found to be the highest in samples collected from Lake Nabugabo (21.10\%) followed by Lake Kachira (8.20\%), Lake Mburo (6.67\%) and Lake Victoria (0.91\%) (Mwanja et al., 1996). Asma (1999) reported that a diagnostic marker (fragment of $1,550 \mathrm{bp}$ ) of tiger barb (P. tetrazona) in green variety was present in Perak population but it was absent in Johor population. Fragment 200 bp produced by primer NUSZG2, NUSZG3 and NUSZG4 was present in sea cucumber samples from Perak locality but it was not present in the other observed localities (Norazila, 2000). Miyanohara et al. (1999) also reported that the genetic difference between the Okinawa and Miyazaki populations of the common silver-biddy (Gerres oyena) was distinguished by the A29-260 marker. This fragment was observed in all Miyazaki samples but it was not observed in the ones of Okinawa.

\section{CONCLUSION}

The ten selected universal primers generated a total of 212 fragments (loci) and 120 polymorphic fragments and their sizes are ranging from 250 to $2,500 \mathrm{bp}$. The high polymorphism (60\%) was obtained from Makassar population followed by Bone (59\%) and Pare-Pare populations (50\%). Similarity index of individuals was $0.86 \pm 0.07$ for Pare-Pare, $0.80 \pm 0.11$ for Makassar and $0.82 \pm 0.07$ for Bone populations. The UPGMA dendrogram seemed to be clus- 
tered according to their geographical locations, where Pare-Pare population was genetically closer to Makassar population ( $D=0.20)$ than to Bone population $(D=0.24)$.

\section{ACKNOWLEDMENT}

The present study was funded by the Agricultural Research Management Project (ARMP phase II) from the Agency for Agricultural Research and Development (AARD).

\section{REFERENCES}

Amstrong, J. S., Gibbs, A. J., Peackall, R., Weiller, G., 1994. The RAPDistance Package. Australian National University, Canberra, Australia, Http://life.anu.au/molecular/ software/rapd.html.

Apun, K., Sani, H., Cheng, A.P., 2000. The use of RAPD to assess somaclonal variation in subcultured plantlets of Nepenthes ampullarria. In: Saad, M.S., Faridah, Q.Z., Kadir, M.A., Khalid, M.Z.Z., Mohamad, O., Saleh, G.B. and Panandam, J.M. (Eds.) Genetic Manipulation: Challenges and Advantages. Proceeding of the $4^{\text {th }}$ National Congress on Genetics, 26-28 Sept.2000, Genting Highlands, Malaysia, p.301-312.

Asahida, T., Kabayashi, T., Saitoh, K., Nakayama, I., 1996. Tissue preservation and total DNA extraction from fish store at ambient temperature using buffer containing high concentration of urea. Fisheries Science 62(5):727-730.

Asma, N. A. 1999. Genetic variation between and within three varieties of domesticated tiger barb (Puntius tetrazona) using RAPD markers. Thesis Faculty of Medicine and Health Sciences, Universiti Putra Malaysia, $115 \mathrm{pp}$.

Bardakci, F., Skibinski, D. O. F., 1994. Application of the RAPD technique in tilapia fish : species and subspecies identification. Heredity 73,1 7-123.

Bardakci, F., Skibinski, D. O. F., 1999. A polymorphic SCAR-RAPD marker between species of tilapia (Pisces:Cichlidae). Animal Genetic 30,78-79.

Bielawski, J. P., Pumo, D. E., 1997. Ramdomly Amplified Polymorphic DNA (RAPD) analysis of Atlantic coast striped bass. Heredity 78,32-40.

Bowditch, B. M., Albright, D. G., Williams, J. G. K., Braun, M. J., 1993. Use of randomly amplified polymorphic DNA markers in compara- tive genomic studies. Methods in Enzymology, 224:294-309.

Crosetti, D., Campton, D. E., Sola, L., 1998a. Genetic divergence and phylogenetic inferences in five of Mugilidae (Pisces:Perciformes). Marine Biology 131, 213-218.

Dahle, G., Rahman, M., Erikksen, A. G., 1997. RAPD fingerprinting used for discriminating among three populations of hilsa shad (Tenualosa ilisha). Fisheries Research 32, 263-269.

D’Amato, M. E., Corach, D., 1996. Genetic diversity of population of the fresh-water shrimp, Macrobrashium borellii (Caridae:Palaemonidae) evaluated by RAPD analysis. Journal of Crustacean Biology 16(4), 650-655.

Elo, K., Ivanoff, S., Vuorinen, J. A., Piironen, J., 1997. Inheritance of RAPD markers and detection of interspecific hybridization with brown trout and Atlantic salmon. Aquaculture 152, 55-65.

Ferguson, A., Taggart, T. B., Prodohl, P. A., McMeel, O., Thompsom, C., Stone, C., McGinnity, P., Hynes, R. A., 1995. The application of molecular markers to the study and conservation of fish populations, with special reference to Salmo. Journal of Fish Biology 47, 103-126.

Fritsch, P., Rieseberg, L. H., 1996. The use of Random Amplified Polymorphic DNA (RAPD) in conservation genetics. In: Smith, T. B., Wayne, R. K., (Eds.) Molecular Genetic Approaches in Conservation. Oxford University Press, New York, pp. 54-73

Garcia, D. K., Benzie, J. A. H., 1995. RAPD markers of potential in penaeid prawn (Penaeus monodon) breeding programs. Aquaculture 130, 137-144.

Groombridge, B. 1992. Global biodiversity; status of the Earth's living resources. A report compiled by the Word Conservation Monitoring Centre. Chapman and Hall, London, $594 \mathrm{pp}$.

Hadrys, H., Balick, M., Shierwater, B., 1992. Applications of random amplified polymorphic DNA (RAPD) in molecular ecology. Molecular Ecology 1, 55-63.

Jorde, L.B. 1995. Population specific genetic markers and diseases. In: Meyers (Ed.). Molecular Biology and Biotechnology: A Comprehensive Desk Reference, VCH Publisher, Inc. New York, USA, pp. 724-728

Kim, C. L. 1998. Development of PCR-based DNA 
markers to identify and characterise Malaysian river catfish, Mystus nemurus (C\&V): RAPD and AFLP. Thesis Master of Science, Faculty of Science and Environmental Studies, Universiti Putra Malaysia, $124 \mathrm{pp}$.

Koh, T. L., Khoo, G., Fan, L. Q., Phang, V. P. E., 1999. Genetic diversity among wild forms and cultivated varieties of discus (Symphysodon spp.) as revealed by Random Amplified Polymorphic DNA (RAPD) fingerprinting. Aquaculture 173, 485-497.

Lim, F.T. 1998. Molecular polymorphisms studies of Malaysian River Catfish, ikan baung (Mytilus nemurus), detected using the RAPD-PCR method. Faculty of Science and Environmental Studies, Universiti Putra Malaysia, Serdang, 88 pp.

Linacero, R., Rueda, J., Vazquez, A. M., 1998. Quantification of DNA. In: Karp, A., Isaac, P. G., Ingram, D. S., (Eds.) Molecular Tools for Screening Biodiversity: Plants and Animals. Chapman and Hall. London, Weinheim, New York, Tokyo, Melbourne, Madras, pp.18-21.

Liu. Z. J., Li, P., Argue, B. J., Dunham, R. A., 1999. Random amplified polymorphic DNA markers: usefulness for gene mapping and analysis of genetic variation of catfish. Aquaculture 174, 59-68.

Manezes, M, R., Parulekar, A. H., 1998. Genetic variation in marine natural populationsmeasurement and utility in resource management and conservation: a review. Indian Journal of Marine Science, p:267-273.

Miyanohara, M., Iwatsuki, Y., Sakai, M., 1999. Analysis of the Okinawa and Miyazaki populations of the common silver-biddy, Gerres oyena using random amplifed polymorphic DNA (RAPD) technique. Fisheries Science 65(2), 177-181.

Mwanja, W., Booton, G. C., Kaufman, L., Chandler, M., Fuerst, P., 1996. Population and stock characterization of Lake Victoria tilapine fisher based on RAPD markers. Aqua. Biotech. Symp. Proceeding, pp:115123.
Nei, M., Li, W., 1979. Mathematical model for studying genetic variation in terms of restriction endonucleases. Proceeding of the National Academic of Science, USA. 76, 5269-5273.

Norazila, K. S. 2000. Genetic polymorphisms in sea cucumbers (Holothuridea) using random amplified polymorphic DNA (RAPD). Thesis Master of Science, Faculty of Medicine and Health Science, Universiti Putra Malaysia.

Rohlf, F. J. 1994. NTSYS-pc Numerical taxonomy and multivariate analysis system. Exeter Software, New York.

Smith, P. J. 1994. Genetic diversity of marine fisheries resources: Possible impacts of fishing. FAO Fisheries Technical Paper 344, 1-8.

Smith, P. J., Benson, P. G., McVeagh,S. M., 1997. Comparison of three genetic methods used for stock discrimination of orange roughy, Hoplostethus atlanticus : Allozymes, mitochondrial DNA, and Random Amplified Polymorphic DNA. Fishery Bulletin 95, 800-811.

Takagi, M., Taniguchi, N., 1995. Random amplified polymorphic DNA (RAPD) for identification of three species of Anguilla, A. japonica, A. australis, and A. bicolor. Fisheries Science 61(5), 884-885.

Tam, B. M. 2000. Study on some aspects of nutrition and genetic variation of freshwater angelfish (Pteropyllum scalare). Master Thesis, Faculty Applied Science and Technology. Universiti Putra Malaysia, Terengganu.

Williams, J. G. K., Kubelik, A. R., Livak, K. J., Rafalski, J. A., Tingey, S. V., 1990. DNA polymorphisms amplified by arbitrary primers are useful as genetic marker. Nucleic Acids Research 18,6531.

Yu, K., Pauls, K. P., 1994. The use of RAPD analysis to tag genes and determine relatedness in heterogeneous plant populations using tetraploid alfalfa as an example. In PCR Technology: Current Innovations, CRC Press Inc. pp:201-214 